\title{
Social, Historical and Psychological Realism in Arundhati Roy's The God of Small Things
}

Dr. Ram Janam

Assistant Professor

Gorakhpur, Uttar Pradesh, India

ramjanam306@gmail.com

\begin{abstract}
The God of Small Things depicts realistic picture of the current issues of the typical Indian society. Arundhati Roy has tried her best to cover almost all the details of social and historical setting so that the readers may be able to acquaint with the pattern of living, daily routine, rites, customs, rituals and habits. The book explores how the small things affect people's behaviour and their lives. During that time in India, class was a major issue and still is in many parts of India. Inferiority complex is clearly visible in the interactions between Untouchables and Touchables in Ayemenem. The novel also shows that The Untouchables were considered polluted beings. Betrayal is also a constant theme in this story. Love, ideals, and confidence are all forsaken, consciously and unconsciously, innocently and maliciously, and these deceptions affect all of the characters deeply.
\end{abstract}

Keywords: Forbidden Love, Betrayal, Untouchability, Misogyny.

Though to present only a realistic picture of the society is not the real business of art and literature, but there is blending of realism and fantasy in writings. Today, we see that the works 
of Shakespeare appeal to universal readers. Why because his works contain the practical wisdom of the world as well as literary value. The same case is with Arundhati Roy who has lived up to the ideals of great art in The God of Small Things. She has depicted the naked truth of the society. There is no doubt in about it. She has never forgotten the rules of art, e.g., images and symbols, overtones and ironies and other associated aspects of a great art.

Arundhati Roy has made a sincere effort to present the realistic picture of the dresses, men and manners of the contemporary Keralite society. Sophie Mol was dressed in her yellow crimplene bellbottoms with her hairs in a ribbon and made in England go go bag that she loved.(4) In the same way, Rahel and Estha are described in terms of their dress and style:

Estha had slanting, sleepy eyes and his new front teeth were still uneven on the ends. Rahel's new teeth were waiting inside her gums like words in a pen most of Rahel's hair sat on top of her head like a fountain. It was held together by a Love in Tokyo two beads on a rubber band nothing to do with love or Tokyo. Rahel's toy wristwatch had the time painted on it. Her airport frock was in Ammu's suitcase. (37)

The detailed description of the paradise pickle factory is a fine example of the realistic picture. We know that this pickle factory is associated with the life of Arundhati Roy. She admits: "I spent the early years of my childhood in my grandmother's pickle factory in Kerala and become a formidable curry-powder packer and pickle label sticker". We get a vivid picture of the pickle factory in chapter10, "The River in the boat".

It is to be noted that one of the chief concern of a great author of realistic writings is to highlight the cause of and to describe the piteous plight of the lowly and the lost, depressed and the deserted. In order to present the true picture of untouchability and other evils which our 
society has undergone, the author gives a detailed description of historical facts also. After the British came to Malabar, a number of low caste people including Kelan Velutha's grandfather became Christian and joined the Anglican Church in the hope of being liberated from the clutches of untouchability. They were also given incentive to promote the cause of Christianity. They were even given little food and money. Perhaps this is why they were known Rice Christian. But very soon they came to know that they had just jumped from the frying pan into the fire. They were given separate churches, separate priests, separate service and through a special favour they were entitled to own a separate Pariah Bishop. Their condition began to worsen after independence when they found that they were not given any benefits provided by the government like job reservation or bank loans at low interests. It was only because they were casteless. Through this historical reference, Roy seems to fling a mild satire on Christianity that boasts of international fraternity and casteless society. She ironically holds the view: "it was a little like having to seep away your footprints without a broom. Or worse, not being allowed to leave footprints at all”.(74)

Moreover, we also get a realistic depiction of the untouchables before independence. Vellya Paapen who is like Bakha in Untouchable by Mulk Raj Anand is always worried about the aristocratic behavior of his son, Velutha who is the product of modern world. He is like Bakha who hesitates to abide by the hard and fast rules of society regarding untouchability. Velutha remembered how he along with his father used to come to the Ayemenem house to deliver coconut plucked from the trees. Pappachi would not allow the Paravans into the house. They were not allowed to touch anything:

Mammachi told Estha and Rahel that she could remember a time in her girlhood when Paravans were expected to crawl backward with a broom sweeping away 
their footprints so that Brahmins or Syrian Christian would not defile themselves by accidently stepping into a Paravan's footprints. In Mammachi’s time Paravans, like other untouchables were not allowed to walk on public road, not allowed to cover their upper bodies, not allowed to carry umbrellas. They had to put their hands over their mouths when they spoke to divert their polluted breath away from those whom they addressed.(73-74).

When Ammu, after the funeral of Sophie Mol took the twins back to the Kottayam police station, she sees the dirty police station- the dirty, smoky stink of old urine that permeated the walls and furniture. The foul smell was unbearable to the nostrils of the twins who shut well before the smell begun. We also get a realistic picture of the dirty urinal in a cinema hall. In this way, Arundhati Roy wants to show the dirty condition of a large number of talkies of India. In the end of the novel we have a realistic vision of the cruelty and persecution of the police. Velutha under the custody of the police has to tolerate physical tortures. Roy realistically and very nicely depicts a vivid picture of the pathetic plight of Velutha.

A close study of the novel The God of Small Things also shows some psychological elements playing vital role in the inner workings of some of the major characters. The characters like Ammu, Estha, Rahel, Baby Kochamma and Velutha are seen suffering from some psychological disturbances. The whole novel seems to revolve around two types of psychologyneeds psychology and trauma psychology. It is teh needs psychology that makes Ammu the breaker of the love laws which is who should be loved and how and how much. The trauma psychology makes Rahel, a boy of taciturnity who always wants to lead a life far from the din and bustle of crowded city. It is this psychology which engraves a permanent imprint in the innocent mind of Rahel who later on develops an incestuous relation. 
If we judge The God of Small Things on the basis of the above-mentioned demands, we come to conclusion that almost all the characters of the novel are suffering from these demands of organism. It is the wish for security which prompts Ammu and her twins to discard social norms and makes them lead a life worse than that of animals. The wish for a new experience makes the twins engage in an incestuous relation. It is this experience which makes Ammu and Velutha indulge in the sexual life that ultimately leads to their death-one is killed by society and the other by callous administration. In short, the denial of the above-mentioned physical and psychological needs makes the characters of the novel rebellious leading to a defiance of society's age old norms.

Ammu gets a traumatic shock when she marries a Bengali man who proves to be a great drunkard. After marriage she discovered that she had jumped out of the frying pan into the fire. Her husband goes to the extent of asking Ammu to satisfy the sexual needs of Mr. Hollick, his boss, so that his job could be saved. This extreme humiliation creates a sense of hatred in the heart of Ammu for her husband. In a scuffle she hits her husband with a big book and leaves the place with her twins.

Ammu returns to Ayemenem with pulled out cheeks and there too she finds her parents cool and indifferent to her and her children. Her eyes well up when she sees the miserable condition of her two children. She imagines her two children "like a pair of small bewildered frogs engrossed in each other's company lolloping arm in arm down a highway full of hurtling traffic"(43). Even Chacko who is educated in Oxford University is seen developing a sense of hatred to her. He tells her cynically "what is yours is mine and what is mine is also mine. Why because Ammu as a daughter, had no claim to the property and she had no Locusts stand I."(57) Moreover, Ammu realizes that youth and beauty will soon be bidding goodbye to her body. She 
discovers it in her bathroom. So in order to satisfy her long buried sexual desire, she goes out in the night, meets her lover Velutha and makes an illicit relation with him. In this act, it is she who takes the initiative.

Thus we see that Ammu is a great victim of the psychological trauma which she experienced in her childhood and just after the marriage. Whatever she dreams comes true. One afternoon the day Sophie Mol arrives, she dreams of 'Dolphins and the deep blue'. She also dreams a one-armed man. The dream is highly suggestive. We know that according to Freud, dream is the fulfillment of all our repressed desires. Here the 'one-armed man suggests Velutha who is handicapped by society administration and Marxism. Just after this dream, she discovers her youth and beauty in the bathroom.

The severest trauma which Ammu encounters in her life is the exposure of her illicit relation with Velutha, the untouchable. Consequently, she has been locked up in the dark room for some hours. She began to behave like insane. Velutha on the other hand is captured and so mercilessly tortured by the police that he breathed his last in the lock up. When Ammu visits the police station the police inspector insults her and Chacko orders her to leave his house. Ammu is so shattered both physically and psychologically that she becomes the victim of patriarchal domination. She ultimately dies in a lodge.

Love is the central theme in Arundhati Roy's novel The God of Small Things. The love relationships in the novel are not always mutual but the majority of the population breaks the social rules. The love between Rahel and Estha is an interesting love and it belongs to its own class of relationship. Chacko's love for Margaret and Sophie is an example of unrequited love. The love affair of Velutha and Ammu is not accepted by the society but it is described as the most justified because of their true love, and mutual appreciation of small things. 
The another traumatic experience which the innocent minds of the novel have to suffer are related to Rahel and Estha who are twins. Right from their birth they have to lead a life of fret and fever, cares and anxieties. They see the quarrels between their mother and father in Assam where their father was an employee in the tea plant. When they go to live in the Ayemenem house, they are treated as outsiders. They become the victim of morbid stiffness and the malice of Baby Kochamma who continuously reminds them of their isolation, their sinfulness etc. The first traumatic experience which the sensitive mind of Estha had was the misbehavior of the orange drink Lemon drink man in the Abhilash Talkies.

Thus we see that the twins are ill- treated by the other members of the family. After the arrival of Sophie Mol they are severely neglected and even denigrated. Psychology shows that a child who is neglected by the family, develops a sense of isolation strong enough to create hurdles in the path of the child's moral and spiritual, physical and social development. Perhaps this is why all through the novel we see that the twins harbor a feeling of anxieties which always haunt them.

The next character suffering from abnormal psychology is Baby Kochamma, who is a Lady Macbeth or central villain of the novel. She develops an extremely puritanical and intolerant attitude. It is she who exposes the reality of Ammu's illicit love affair with Velutha. It is she who frightens the twins and compels them to speak against Velutha in the police station. In other words she seems to be an embodiment of strictness, rigidity and hypocrisy. Outwardly, she behaves like a lady of decorum and decency, etiquette and manner, but inwardly she is rotten, full of poison.

The answer can be sought in psychology, particularly in the frustration psychology. Psychology denotes that if a man's ardent desire in his early life is crushed or suppressed, it burst 
like a lava of volcano in his later life. In other words disappointment, frustration or repressed sentiments begin to take its toll in the sufferer's life. The sufferer's mind is fractured with so much psychological maladies that he begins to develop a sadistic attitude so that his long suppressed desires may be compensated. Thus a thorough study very clearly shows some psychological things gaining ground in almost all the chief characters of the novel.

After all it can be said that love, hatred, betrayal and social discrimination has been described very beautifully by the novelist. The God of Small Things is predominantly a love story. One interpretation of Roy's theme of forbidden love is that love is such a powerful and uncontrollable force that it cannot be controlled by any conventional social code. Other thing is that conventional society somehow seeks to destroy real love that is why love in the novel is consistently connected to loss, death, and sadness which is seen in the present society. If there is true love and mutual understanding between lovers, it should not be prevented by the society on the basis of caste, creed and social discrimination. 


\section{Works Cited}

Bhatt, Indira and Nityanandam, Indira, ed. Explorations: Arundhati Roy's The God of Small Things. New Delhi: Prestige Books, 1999.

Earnshaw, Steven. Beginning Realism. New Delhi: Viva Books Pvt. Ltd., 2010.

Freud, Sigmund. The Anatomy of the Mental Personality. New Introductory Lectures on Psychoanalysis. New York: Norton, 1964.

Morris, Pam. Realism: The New Critical Idiom. New York: Routledge, 2013.

Roy, Arundhati. The God of Small Things. New Delhi: Indialnk Publishing Co. Pvt. Ltd, 1998.

Sharma, R.S. Arundhati Roy's The God of Small Things: Critique and Commentary, New Delhi: Creative Books, 1998.

Wikipedia contributors. "The God of Small Things." Wikipedia, The Free Encyclopedia. Wikipedia, The Free Encyclopedia, 11 Apr. 2020. Web. 